\title{
Late Quaternary paleoseismic sedimentary archive from deep central Gulf of Corinth: time distribution of inferred earthquake-induced layers
}

\author{
Corina Campos ${ }^{1,2, \star}$, Christian Beck ${ }^{2}$, Christian Crouzet $^{2}$, Eduardo Carrillo $^{3}$, \\ Aurélien Van Welden ${ }^{4,2}$, Efthymios Tripsanas ${ }^{5}$ \\ ${ }^{1}$ Universidad Simón Bolivar, Departamento de Ciencias de la Tierra, Sartenejas, Baruta, Venezuela \\ ${ }^{2}$ Grenoble-Alpes University, Laboratoire ISTerre, UMR CNRS 5275, CISM, Le Bourget du Lac, France \\ ${ }^{3}$ Universidad Central de Venezuela, Instituto de Ciencias de la Tierra, Caracas, Venezuela \\ ${ }^{4}$ Fugro Survey AS, Skøyen, Oslo, Norway \\ ${ }^{5}$ Institute of Oceanography, Hellenic Centre for Marine Research (HCMR), Anavyssos, Greece
}

\author{
Article history \\ Received November 16, 2012; accepted December 20, 2013. \\ Subject classification: \\ Homogenite, Paleoseismicity, Anisotropy of magnetic susceptibility, Corinth.
}

\section{ABSTRACT}

A sedimentary archive corresponding to the last 17 cal kyr BP has been studied by means of a giant piston core retrieved on board R/V MARION-DUFRESNE in the North Central Gulf of Corinth. Based on previous methodological improvements, grain-size distribution and Magnetic Susceptibility Anisotropy (MSA) have been analysed in order to detect earthquake-induced deposits. We indentified 36 specific layers -Homogenites +Turbidites (HmTu) - intercalated within continuous hemipelagictype sediments (biogenic or bio-induced fraction and fine-grained siliciclastic fraction). The whole succession is divided into a non-marine lower half and a marine upper half. The "events" are distributed through the entire core and they are composed of two terms: a coarse-grained lower term and an upper homogeneous fine-grained term, sharply separated. Their average time recurrence interval could be estimated for the entire MD01-2477 core. The non-marine and the marine sections yielded close estimated values for event recurrence times of around 400 yrs to 500 yrs.

\section{Introduction}

Following different studies achieved in tectonically active areas, lake and restricted marine basins have demonstrated their potential for the sedimentary recording of seismic shocks [e.g. Hempton and Dewey 1983, Siegenthaler et al. 1987, Van Loon et al. 1995, Syvitski and Schafer 1996, Mörner 1996, Chapron et al. 1999, Shiki et al. 2000, De Batist et al. 2002]. Two major mechanisms may account for this recording: i) in situ disturbances (micro-fracturing, micro-folding; liquefaction, injection; [e.g. Rodriguez-Pascua et al. 2000,
Marco and Agnon 1995, Levi et al. 2006], ii) slope failures and gravity redeposition, associated, or not, to tsunamis or seiche effects. Our investigations concern the second case.

Mass wastings (triggered, or not, by seismic shocks) evolving into gravity flowing (density/turbidity currents) may provide large areas for spreading and produce "classical" turbidites (with the differents terms defined by Bouma [1962] or Mutti and Ricci Lucchi [1978]; Piper and Normark [2009]). Conversely, when occurring in more confined (or restricted) basins (lakes or isolated marine basins) re-depositional processes may result into specific complex layers, due to reflections on steep slopes and/or to oscillations of the whole water mass (reflected tsunami, seiche effect). More often, a significant seismo-tectonic activity is responsible for the second type of sedimentary "event", the reason for which it is particularly searched for paleoseismic purpose and contribution to seismic hazard estimation.

The main characteristics of these sedimentary events are: i) a sharp limit at the top of a coarse graded lower part, ii) a structureless highly homogenous finegrained upper part [Sturm et al. 1995, Siegenthaler et al 1987, Chapron et al. 1999, Beck et al 2007]. Additionally, a mixed term-indicating to-and-fro particle displacements-is often observed in between; it may be directly visible trough X-ray imaging [Beck et al. 2007] or be detected with high-resolution grain-size evolu- 
tion (which is proposed for the here-presented examples). The basal layer is coarser-grained and may vary from very thin silty laminae to thick sandy/gravelly normal graded layer as the lower term of a turbidite sensu Bouma [1962] and Mutti \& Ricci Lucchi [1978]; it may consist of several pulses with an overall grain-size decrease. The upper unit is a fine-grained homogeneous term, named "homogenite" $(\mathrm{Hm})$ in reference to the concept of Kastens and Cita [1981]. After the discovery of the Mediterranean tsunami-induced finegrained "homogenite" [Kastens and Cita 1981, Cita et al. 1996], similar homogeneous layers have been reported in lakes and closed marines basins and have been associated to subaqueous earthquake-effects [Sturm et al. 1995, Chapron et al. 1999, Beck et al. 2007, Bertrand et al. 2008, Carrillo et al. 2008, Çağatay et al. 2012]. This interpretation (especially the importance of a long-lasting suspension settling under oscillatory conditions at the beginning) has been confirmed by recent observations made immediately after major earthquakes in the Cariaco Trough [Thunell et al. 1999] and north-west Haiti [McHugh et al. 2011]. They indicate the presence of a long-lasting "cloud" of fine particles that remained in suspension for several weeks, and which is responsible for the deposition of homogeneous layers. Thus, in this work we will focus on the occurrences of such associations homogenite+turbidite (named here $\mathrm{HmTu}$ ) and their time-dis- tribution along a long core from the Gulf of Corinth [Moretti et al. 2004, Lykousis et al. 2007].

\section{Geological setting}

The Aegean region is one of the most active extensional continental regions around the world [McKenzie1972, 1978, Le Pichon et al. 1981]. It is moving up to 30 $\mathrm{mm} / \mathrm{yr}$ to the southwest with respect to Eurasia and progressively migrates to the south [McClusky et al. 2000, Jolivet 2001]. Within this framework, the Gulf of Corinth, a semi-enclosed marine basin located in Central Greece (Figure 1), represents one of the most recent extensional features in the area. It is an active half-graben and is bounded by E-W striking, en echelon faults located onshore and offshore [Brooks and Ferentinos 1984, Armijo et al. 1996, Sakellariou et al. 2001]. The focal mechanism solutions indicate a main direction of extension N-S [McKenzie 1978, Jackson et al. 1982, Bernard et al. 2006]. Geodetic data show that the active extension is focused offshore, increasing from $11 \mathrm{~mm} / \mathrm{yr}$ in the central part of the rift (near Xylocastro) to $16 \mathrm{~mm} / \mathrm{yr}$ in its western part (near Aigion) [Avallone et al. 2004]. The gulf has a maximum uplift rate of $1.3 \mathrm{~mm} / \mathrm{yr}$ in the southemargin [Armijo et al. 1996]. It is $115 \mathrm{~km}$ long, $30 \mathrm{~km}$ wide, with a $900 \mathrm{~m}$ maximum depth (Figure 1). It is characterized by steep north and south dipping slopes $\left(8^{\circ}-25^{\circ}\right)$ [Stefatos et al. 2002]. To the west, the gulf is separated from the open marine Ionian Sea by the Rion-Antirion strait $(2 \mathrm{~km}$ wide

$22^{\circ} 00$

$22^{\circ} 30$

$23^{\circ} 00$

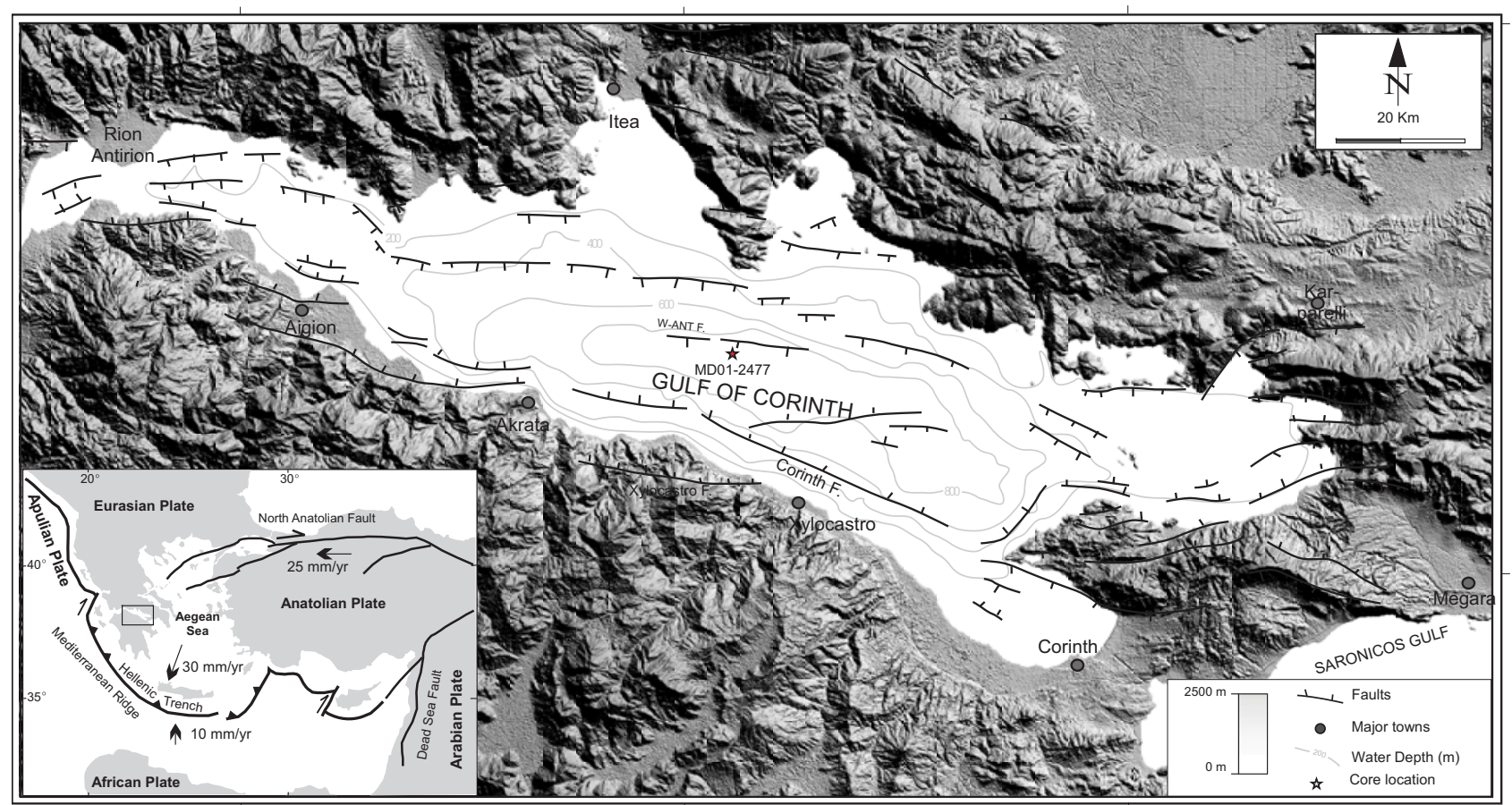

$22^{\circ} 00$

$22^{\circ} 30$

$23^{\circ} 00$

Figure 1. Simplified geodynamic setting of the Gulf of Corinth with the location of the MD01-2477 core. The locations of major faults and the bathymetry are from Moretti et al. [2003] (200 $\mathrm{m}$ isobaths intervals); onshore relief is an extract from NASA/SRTM. Motion vectors of the North Anatolian fault after Le Pichon et al. [1995], and of the Aegean and African plates relative to Eurasia after McClusky et al. [2000]. 
and $65 \mathrm{~m}$ deep). To the east, it is linked with the Saronikos Gulf and the western Aegean Sea through an artificiallydredged channel (the Corinth Canal), which is $6.3 \mathrm{~km}$ long, $21 \mathrm{~m}$ wide and $8 \mathrm{~m}$ deep.

\section{Methodology}

The paleoseismic record in the Gulf of Corinth was studied using the MD01-2477 long piston core, recovered during a R/V MARION-DUFRESNES cruise as part of GEOSCIENCES-II program, carried out in October 2001. This Calypso piston core was taken in the central part of the Gulf of Corinth at $38^{\circ} 13.28^{\prime} \mathrm{N}$, $22^{\circ} 33.53^{\prime} \mathrm{E}$ and $867 \mathrm{~m}$ water depth. The core is $20.08 \mathrm{~m}$ long (Figure 2), and it is supposed to represent the last 25.3 cal. kyr BP of sedimentation [Moretti et al. 2004, Lykousis et al. 2007]. Shipboard processing included GEOTEK core logger profiles and splitting; further laboratory samplings and measurements were done on half cores horizontally stored at $4^{\circ} \mathrm{C}$.

To characterize and discriminate homogenites from other fine-grained deposits, analysis of the textural parameters is the most common tool [Chapron et al. 1999, Beck et al. 2007, Carrillo et al. 2008, Bertrand et al. 2008], especially those depending on particles arrays. The combination of grain size, undrained shear stress, and magnetic fabric has been used to get a wellconstrained characterization of the homogenites and their temporal distribution [Chapron et al. 1999, Carrillo et al. 2008, Bertrand et al. 2008, Beck 2009]. Recent works show the importance of the application of the Magnetic Susceptibility Anisotropy (MSA) in the study and identification of post-depositional disturbances related to earthquake triggering [Levi et al. 2006, Mörner and Sun 2008]. When previously settled deposits include hemipelagites, the fine-grained resuspended fraction (incipient homogenite) may be very similar (grain-size and composition) to these hemipelagites. MSA appears to be a useful tool to establish this distinction [Campos et al. 2011, Campos et al. 2013], and, thus, precisely measure the thickness of a hemipelagic interval. The latter represents the time elapsed between two successive reworking events; its duration may thus be considered as an earthquake recurrence time interval [Adams 1990, Gorsline et al. 2000, Goldfinger et al. 2003, Huh 2004].

The here-used age / depth curve is based on this assumption: sedimentation rates estimated from hemipelagic thicknesses, zero-time applied to homogenites+turbidites (HmTu) "events" [e.g. Goldfinger 2009, McCalpin 2009 and references therein, Beck et al. 2012]

After visual identification of specific sedimentary "events" ( $\mathrm{HmTu})$, a detailed textural characterization was applied to selected ones. Two of them (blue rectangle on Figure 2) are presented and discussed here: i) the thickest one, which permitted a high resolution analysis with respect to the thickness, ii) a thinner one more representative of the whole "events".

\subsection{Grain size and shape analysis}

The grain size-analyses were conducted using a laser diffraction microgranulometer MALVERN ${ }^{\mathrm{TM}}$ Mastersizer 2000, which has a 0.02 to $2000 \mu \mathrm{m}$ range. Measurements were performed in the ISTerre laboratory, Savoie University, France, with sampling intervals varying from 0.5 to $2 \mathrm{~cm}$. The distribution parameters have been calculated following Folk and Ward [1957]: skewness index (Sk), sorting index (So), kurtosis. Sk and So were plotted on simple binary diagrams. Percentiles $99(\mathrm{Q} 99=\mathrm{C})$ and medians $(\mathrm{Q} 50=\mathrm{M})$ were plotted on the CM Passega [1964] diagram. Both diagrams were used, as proposed in Beck [2009], to display and analyse bottom-to-top paths. Shape analyses were performed on silt-clay fraction using a Sysmex FPIA-2100 size and shape particle image analyzer, with a sampling interval of $\sim 50 \mathrm{~cm}$.

\subsection{Magnetic properties}

High-resolution bulk magnetic susceptibility data (Figure 2) was collected using a Bartington ${ }^{\mathrm{TM}}$ MS2 contact sensor every $5 \mathrm{~mm}$. The magnetic susceptibility anisotropy (MSA) samples were collected into 8 $\mathrm{cm}^{3}$ non-magnetic plastic boxes and a total of 263 samples were analysed. The measurements were carried out in the CEREGE Magnetism Laboratory (Aix - Marseille University, France) using the MFK1-FA Kappabridge of AGICO (spinning specimen method). For each sample, the system reconstructs the AMS tensor ellipsoid, defined by three eigenvectors $\left(\mathrm{k}_{\max }\right.$, $\mathrm{k}_{\text {int }}$ and $\mathrm{k}_{\text {min }}$ ) [Hrouda 1982, Tarling and Hrouda 1993]. This susceptibility ellipsoid represents the combined result of the susceptibility anisotropy produced by individual grain shape and/or crystallography in a sample [Joseph et al. 1998]. The shape of the MSA ellipsoid is illustrated by several parameters defined by Jelinek [1981], such as $\mathrm{L}=\mathrm{k}_{\max } / \mathrm{k}_{\text {int }}$ and $\mathrm{F}=\mathrm{k}_{\text {int }} / \mathrm{k}_{\text {min }}$.

Only the major events ( 6 to $74 \mathrm{~cm}$ thick) were sampled for textural (every $5 \mathrm{~mm}$ ) and MSA (every 20 $\mathrm{mm}$ ) studies; two of them were selected (A and B intervals, position on Figure 2) as representative of the whole set. Figure 3 and 4, respectively, present the results for a $74 \mathrm{~cm}$ thick event $(30 \mathrm{~cm}$ thick basal Tu term and $44 \mathrm{~cm}$ thick upper $\mathrm{Hm}$ term) and a $17 \mathrm{~cm}$ thick event $(8 \mathrm{~cm}$ thick basal Tu term and $9 \mathrm{~cm}$ thick upper $\mathrm{Hm}$ term). For the first event, a total of 185 measurements were performed (148 for grain-size dis- 

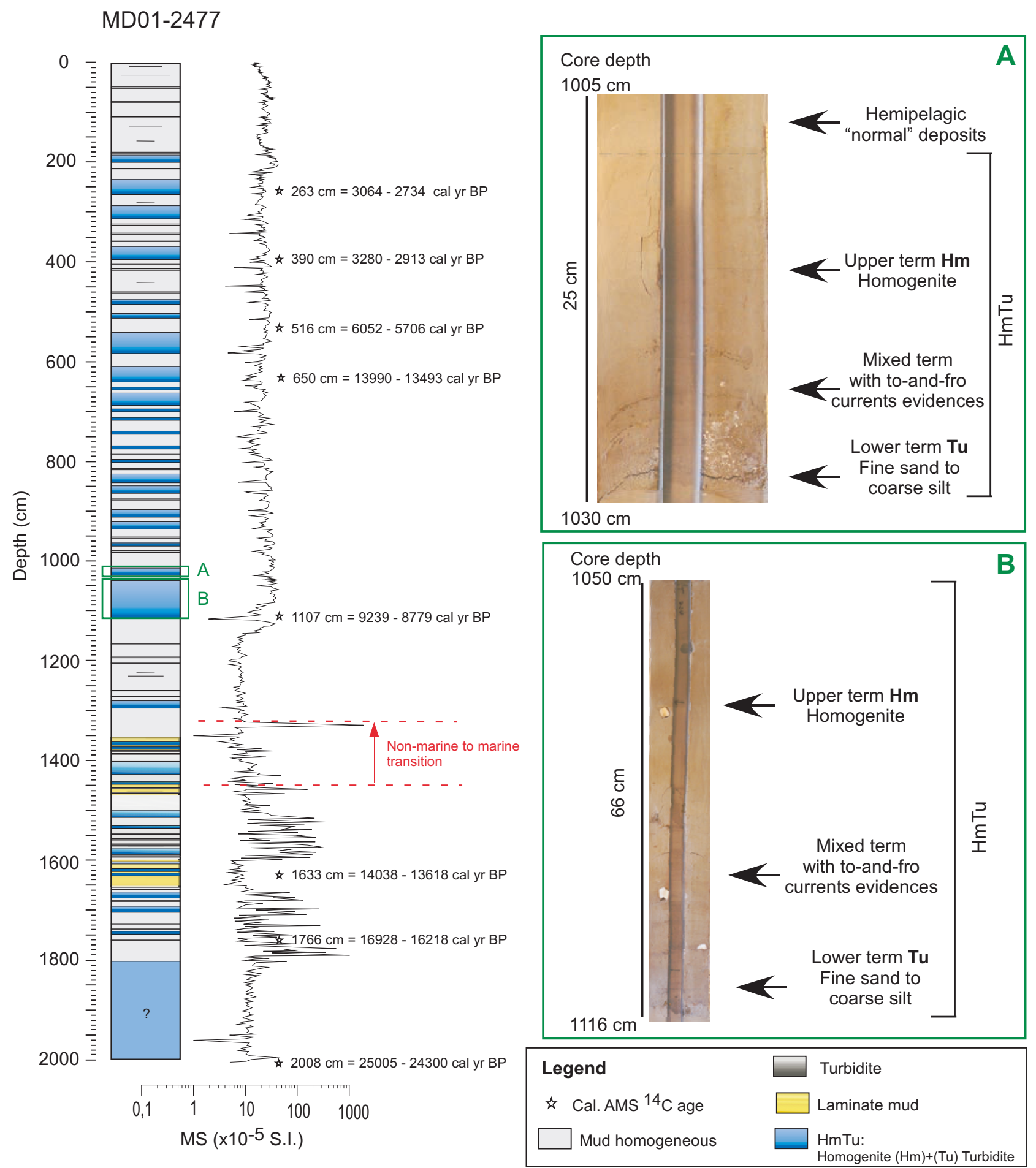

Figure 2. Simplified log of Core MD01-2477 displaying the distribution of the two types of sedimentary events. T: classical turbidites (grey); HT: association "homogenite + turbidite" (blue). The magnetic susceptibility (MS) profile underlines the difference between marine and nonmarine successions. Rectangles refer to the two analyzed layers and their close up (on Figure 3 and 4).

tribution and 37 for MSA parameters).

\subsection{Chronology}

Two sets of Accelerator Mass Spectroscopy ${ }^{14} \mathrm{C}$ measurements are used: 1) published preliminary dating performed by Moretti et al. [2004] and Lykousis et al. [2007] in BETA ANALYTIC Laboratory (USA). 2) A new set of radiocarbon ages obtained at Poznan Ra- diocarbon Laboratory (Poland). The measures were performed on plant debris and wood fragments from coarse to fine turbidites ( 7 measures, Table 1 ) and particulate organic matter collected from organic rich muds ( 1 measure). Radiocarbon ages were calibrated using OxCal-v4 software [Bronk Ramsey 2001]. As the samples were taken in subaquatic environments (marines and non-marine), we use the Marine09 cali- 

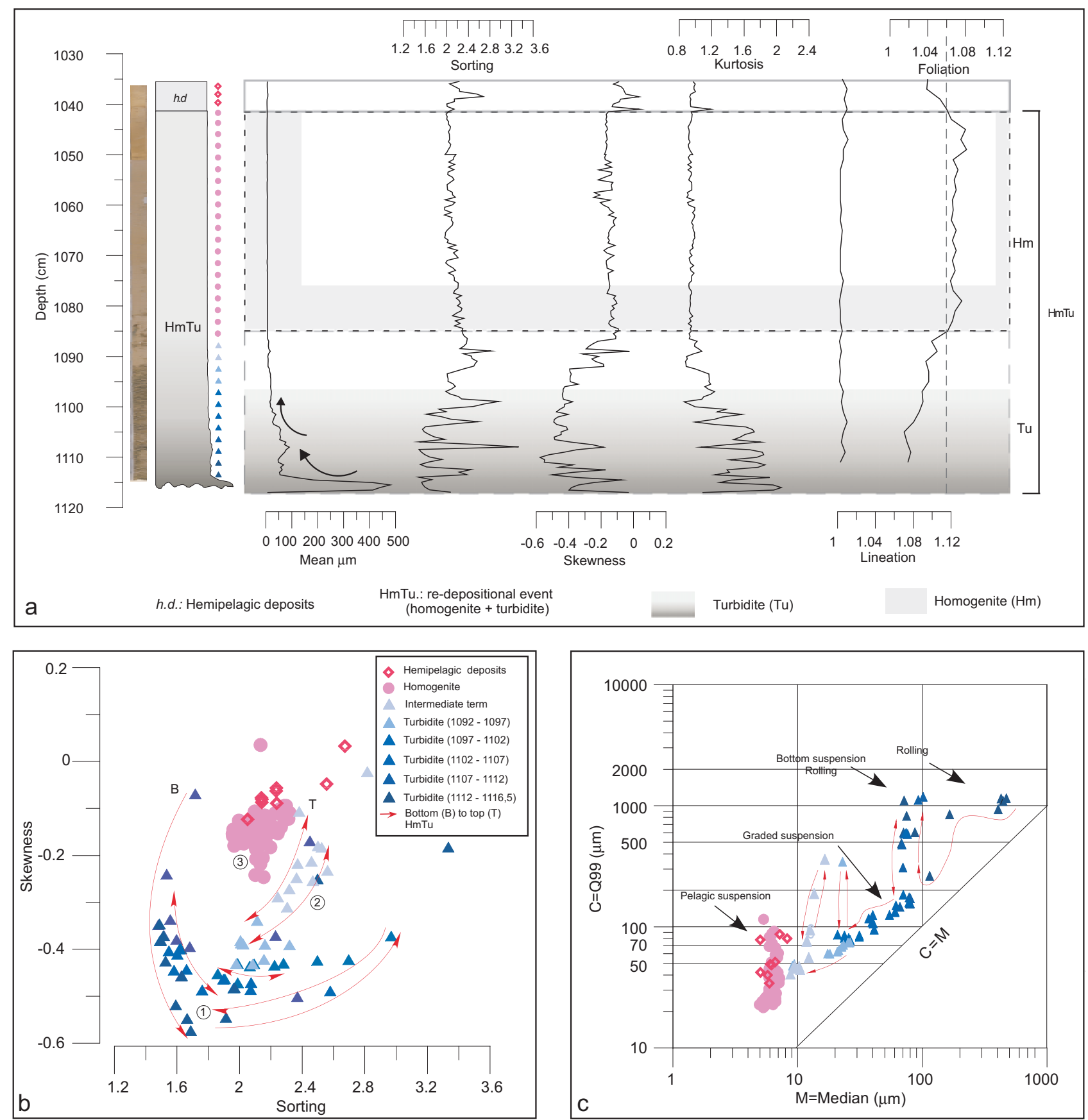

Figure 3. Textural characterization of Homogenite+Turbidite (HmTu) B (1035-1115 cm; location on Figure 2). a) main granulometric parameters and MSA values; b) Sk index vs. So index bottom-to-top path; c) bottom-to-top path on Passega [1964]'s diagram. All textural parameters show a sharp break between turbiditic lower part and overlying homogenite.

bration curve [Reimer et al. 2009], and the local marine reservoir correction $(\Delta \mathrm{R})$ proposed by Reimer and McCormac [2002] for the Aegean Sea. They proposed a $\Delta \mathrm{R}=35 \pm 50 \mathrm{yr}$ for Nafplio, Greece (at $70 \mathrm{~km}$ from the Gulf of Corinth) and $\Delta \mathrm{R}=143 \pm 41 \mathrm{yr}$ for Piraeus, Greece (at $30 \mathrm{~km}$ from the Gulf of Corinth). To use a single value of $\Delta R$ we calculate the average value of both $\Delta R$ with their average errors: $\Delta R=$ $89 \pm 58$. We applied this $\Delta \mathrm{R}$ to the whole sedimentary sequence (marine and non-marine conditions; Holocene and Late Pleistocene). This assumption is probably simplistic, but the lack of data does not allow
In the MD01-2477 core, two types of deposits linked to density currents and reworking processes have been identified, intercalated within the predominant mud. These depsosits are:

1) Turbidites ( $\mathrm{Tu}$ ); they are present as 0.5 to $2 \mathrm{~cm}$ thick layers, made of silt to very fine sand. They can show sharp (sometimes clearly erosive) bases, slight normal grading typical of classical turbidites defined by Bouma [1962], and Mutti \& Ricci Lucchi [1978]. Otherwise, they locally present inverse gradations;

2) Homogenite+Turbidite associations ( $\mathrm{HmTu})$ : They are composed by two main terms (see introduc- 

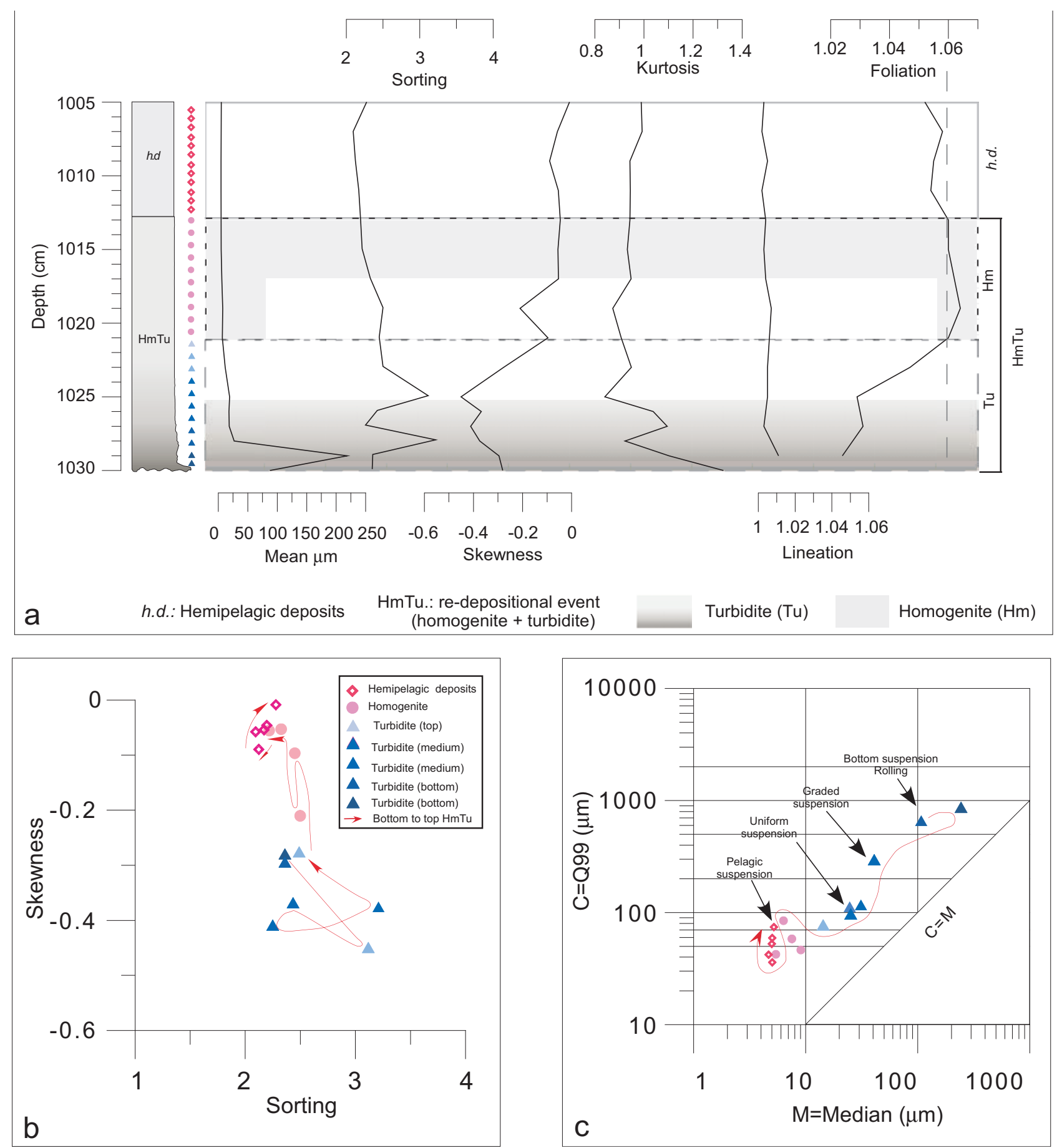

Figure 4. Textural characterization of Homogenite+Turbidite (HmTu) A (1005-1030 cm; location on Figure 2). a) main granulometric parameters and MSA values; b) Sk index vs. So index bottom-to-top path; c) bottom-to-top path on Passega [1964]'s diagram.

tion) with a sharp contact. At this level, oscillation sedimentary structures, that may be direcly eye-visible in between [Beck et al. 2007], were detected here through high resolution microgranulometric profiles and MSA following the methodology proposed by Campos et al. 2013. In the following paragraphs, these textural properties - used as criteria to address relationships between sedimentation and seismicity - are detailed.

\subsection{Textural properties of the HmTu events}

In the MD01-2477 core, $36 \mathrm{HmTu}$ events (6 to 74 $\mathrm{cm}$ thick) were identified through sedimentological observations. We will focus on the two selected events (see 3.2), detailing first the larger one (Event B, Figure 3 ) and then comparing the results with the smaller one's (Event A, Figure 4). Other events, with intermediate thicknessses, are similar to the here-presented ones, and are not detailed hereafter.

For Event B, The basal term (Tu) has a main grain size which progressively decreases from 500 to $9 \mu \mathrm{m}$. The parameters as sorting (2.364 \pm 0.418$)$, skewness ($0.369 \pm 0.120)$ and kurtosis $(1.321 \pm 0.340)$ are highly 


\begin{tabular}{|c|c|c|c|c|}
\hline $\begin{array}{l}\text { Depth in core }(\mathbf{m}) \\
\text { in core }(\mathbf{m})\end{array}$ & $\begin{array}{l}\text { Age } \\
(\mathbf{y r})\end{array}$ & $\begin{array}{l}\text { Age } \\
\text { error }\end{array}$ & $\begin{array}{l}\text { Calibrated } \\
\text { 14C age }(2 \sigma)\end{array}$ & Material \\
\hline 2.63 & 3190 & 40 & $3071-2730$ & PDOM \\
\hline 3.9 & 3355 & 34 & $3301-2907$ & PDOM \\
\hline 5.16 & 5590 & 40 & $6082-5701$ & PDOM \\
\hline 6.5 & 12420 & 60 & $13990-13493$ & PDOM \\
\hline 11.07 & 8500 & 50 & $9251-8763$ & PDOM \\
\hline 16.33 & 12470 & 60 & $14040-13614$ & PDOM \\
\hline 17.66 & 14000 & 100 & $16946-15987$ & PDOM \\
\hline $20.08^{a}$ & 21133 & 110 & $25005-24300$ & POM \\
\hline
\end{tabular}

Table 1. Radiocarbon dating from the MD01-2477 core. The sample denoted by the letter "a" was carried out by Lykousis et al. [2007]. The ${ }^{14} \mathrm{C}$ ages were calibrated using OxCal software [Bronk Ramsey 2001], the Marine09 calibration curve [Reimer et al. 2009]; and applying the local marine reservoir correction $(\Delta \mathrm{R})$ proposed by Reimer and McCormac [2002] for Aegean Sea. Samples in italic overestimate the expected age. $\mathrm{PDOM}=$ plant debris and wood fragments extracted from fine and coarse turbidites; $\mathrm{POM}=$ particulate organic matter extracted from organic rich muds.

variable. Their variability gradually decreases to the top of this unit (Figure 3a). Contrary to Tu, the upper $\mathrm{Hm}$ term (44 $\mathrm{cm}$ thick) have parameters highly constant $($ mean $=5.486 \pm 0.470 \mu \mathrm{m}$, sorting $=2.758 \pm 0.987$, skewness $=-0.150 \pm 0.034$ and kurtosis $=0.945 \pm 0.035$ ). As the $\mathrm{Hm}$ term, the above hemipelagic deposits show almost constant parameters $($ mean $=5.860 \pm 1.167 \mu \mathrm{m}$, sorting $=2.346 \pm 0.431$, skewness $=-0.066 \pm 0.043$ and kurtosis $=0.964 \pm 0.027)$. The grain-size parameters do not clearly separate the hemipelagic deposits from the upper homogeneous unit; at the opposite, the limit is neat on magnetic foliation profile (see after). The bottom-to-top grain-size distribution displays a three-step evolution both on skewness / sorting and CM (Passega's) diagrams (Figure 3-b and 3-c): (1) Basal turbidite (dark blue triangles). (2) Intermediate term (light blue triangles). (3) Homogenite (pink dots). Red arrows underline detail evolutions within the three terms. The following has to be underlined:

- a neat separation between three steps: especially between $\mathrm{Hm}$ and underlying terms well evidence on both diagrams;

- a neat separation between $\mathrm{Tu}$ and intermediate term;

- complex variations within the Tu term

- the individualisation of the intermediate terms with internal variations corresponding to oscillations; we propose to call it "to-and-fro" interval.

An additional remark concerns the $\mathrm{Hm}$ and the hemipelagites, which are not separated, especially on the CM diagram, and which may indicate similar composition and slow settling from suspension.

In the studied section (Figure 3a), the MSA measurements show a low anisotropy (mostly oblate type ellipsoid), excepted in the homogenite. The magnetic lineation is very low and relatively constant $(\mathrm{L}=1.005 \pm$ 0.002). At the difference, magnetic foliation displays significant variations and anomalously high values with respect to expected compaction in the $\mathrm{Hm}$ term $(\mathrm{F}=$ $1.069 \pm 0.005)$ compared to the basal Tu term $(\mathrm{F}=1.032$ $\pm 0.011)$. The hemipelagic deposits $(\mathrm{F}=1.047 \pm 0.009)$ appear significantly lower than for the $\mathrm{Hm}$ term, with a neat limit. This difference has been previously underlined by different authors [Beck 2009, Campos et al. 2013] in marine and lacustrine settings. These authors have shown magnetic foliation in $\mathrm{Hm}$ up to 1.090, in similar sediments with same age and depth in cores with the same coring device.

The second - thin-HmTu (Event A, Figure 4), has been analyzed following the same sampling intervals and measurements as the first - thick - one. The general bottom-to-top evolution appears similar, although not so complex within the lower term. The intermediate term is present; the fact of not displaying the "to-and- 
fro" signature may be due either to its actual lack, or to a too low sampling frequency unable to evidence it.

The characteristics displayed by the two here-presented HmTu sedimentary "events" may be extended to the $36 \mathrm{HmTu}$ occurring along the MD01-2477 core.

\section{Discussion}

\subsection{Interpretation of the sedimentary HmTu event}

The analyzed textural parameters show a clear difference between the two main terms which constitute the HmTu deposit. The basal coarse term shows that this unit was deposit by processes of traction and fall-out [Passega 1964, Lowe 1982, Mutti et al. 1999]. This term in the CM diagram (Figure 3c, 4c) shows a progressive transformation of the transport mechanism of the sediments. The base is characterized by an intense near-bed transport of coarse particles (coarse sand) forming a traction load, in a density flow [Passega 1964, Mulder and Alexander 2001]. In the middle and upper part of this term, composed mostly by fine sand and silt, the sediments are mainly transported in suspension by turbulent flows [Mutti et al. 1999]. Furthermore, the high variability in the skewness and sorting (Figure $3 \mathrm{~b}$ ) indicate fluctuations in the depositional dynamic. Additionally, the presence of two fining-upward sequences within the same basal unit could reflect different pulses of the gravity current, as described by Shiki et al. [2000] and Nakajima and Kanai [2000] in seismo-turbidites from Japan.

The upper homogeneous term shows a highly constant distribution of the textural parameters (Figure $3 b, c$, Figure $4 b, c)$, indicating a stabilization of the energy of the depositional environment, and fallout from a suspended load. Three interesting points have to be explained: the sharp separation of the $\mathrm{Hm}$ term, its thickness and extreme homogeneity, and the intermediate "to-and-fro" term. As previously proposed [Chapron et al 1999, Beck et al 2007], we explain the latter as fluctuations within a high-density suspension whose relative stability is due to lateral oscillatory displacements of the whole water column; coeval partial settling is inferred. This intermediate episode is considered responsible for an increased "extraction" of the finer-grained fraction, which will be the major component of a long-lasting (almost stable) suspension. Based on base-to-top evolutions on the two types of binary diagrams, Arnaud et al. [2002] and Lignier [2001], in: Beck [2009] identified, in a lake infill, two different paths deciphering "flood turbidites" from "slump turbidites", respectively related to tributary flooding and to collapse of deltaic fore- sets. The here-obtained paths clearly resemble their "slump turbidite" path, but with a significant difference, the intercalation of the intermediate "to-andfro" term.

The MSA foliation parameter (F) also confirms the difference between the lower $(\mathrm{Tu})$ and the upper $(\mathrm{Hm})$ terms; a major difference also appears between the $\mathrm{Hm}$ term and the overlying hemipelagic deposit.

In summary, the here-used textural characterization points out a particular and complex depositional mechanism involving, for each event, density/turbidity current (mass wasting and fluidisation), to-and-fro bottom current (related to water mass oscillation), and quiet long-lasting settling of fine-grained homogenous suspension. Seismic shocks and/or subaqueous landslides in closed basins may account for the whole process, especially the whole water column movement (constrained tsunami or seiche effect). This interpretation has been proposed for different marine or lacustrine basins developed in areas with frequent and strong seismic activity [Sturm et al. 1995, Chapron et .al. 1999, Beck et al. 2007, 2012, Bertrand et al. 2008, Carrillo et al. 2008, Çağatay et al. 2012].

\subsection{Triggering mechanism of sedimentary $\mathrm{HmTu}$} events

$\mathrm{HmTu}$ associations were found throughout the whole MD01-2477 (Figure 2). These units, resulting from gravity re-depositional processes, represent a specific evolution of slope failures and mass-wasting. The Gulf of Corinth is well known for the numerous submarines gravitational mass movements as slides, slumps and debris/mud flows [Brooks and Ferentinos 1984, Papatheodorou and Ferentinos 1997, Hasiotis et al. 2002, Lykousis et al. 2007]. In the Gulf, the main mechanisms responsible for these observed mass movements are: (1) the frequent seismic activity in the region, (2) the development of rapid prograding prodeltas associated with high sedimentation rates of the numerous river mouths, (3) the steep slopes and (4) the presence of gas-charged sediments [Hasiotis et al. 2002, Lykousis et al. 2009].

Additionally, historical observations in the Gulf of Corinth give evidence of earthquake induced nearshore sediment failure. Several may be cited, among others: the 373 BC, 1817 and 1861 events [Papadopoulos 2003 and references therein], the 1965 event [Ambraseys 1967], the 1981, 1989 and 1995 events [Perissoratis et al. 1984, Papadopoulos 2003, Ambraseys and Synolakis 2010]. Beside, few aseismic submarines gravitational slide have been reported as the 1963 and 1996 events [Galanopoulos et al. 1964, 
Papadopoulos 2003]. Despite the presence of sediment failure of aseismic origin, earthquakes remain the main cause of submarine failure. In the Gulf of Corinth the earthquakes and the sediment failures of seismic or aseismic origen can generate high amplitude tsunami waves [Dominey-Howes 2002, Papadopoulos 2003, Ambraseys and Synolakis 2010]. These authors have reported a high frequency oscillation (amplitude of $20-30 \mathrm{~cm}$ ) immediately after the 1981 earthquake, with a gradual attenuation during four days after the earthquake [Papadopoulos 2003].

In this study, the gravity-reworked deposits HmTu present in the MD01-2477 core occured farther back in time, when no historical data are available. Therefore, it is not possible to correlate them with the documented historical earthquakes. Despite this, several arguments led us to consider HmTu desposits as earthquake-induced: (1) the drilling site location in the basin plain, avoiding coarser fluxes at tributary river mouths, (2) the high seismic activity in the region, (3) the well known earthquake-induced sediment failures during the last 2000 yrs (4) and the similarities of the HmTu deposits with previous documented earthquake-triggered homogenites+turbidites deposits in marine and lacustrine environments.

The specific planar array in the homogenites (high magnetic foliation values), the sharp contacts within $\mathrm{HmTu}$, and the sedimentary structures typical of to-and-fro currents fit with the hypothesis of major earthquakes inducing coeval gravity reworking and seiche effects [Chapron et al. 1999, Beck 2009 and references therein, Campos et al. 2013]. In these cases, the seiche effect is responsible for: (1) the increase of suspended load by the additional extraction of the clayey-silt matrix from the initial flux, (2) the generation of a sharp contact between the two HmTu main terms by oscillatory bottom currents, (3) and the creation of specific settling conditions, producing the specific planar array (phyllosilicates homogeneous orientation) in the homogenites.

\section{Time distribution of the sedimentary "events"}

On Figure 5, we represent the vertical and temporal distribution of all $\mathrm{HmTu}$ events recognized in the MD01-2477 core, and the sedimentation rates for the hemipelagic deposits (blue colour). The age vs. depth graph was constructed using six radiocarbon ages, assuming a constant sedimentation rate in between, which is most probably oversimplified. The mean rates of sedimentation - and the estimation of the main HmTu recurrence time interval - were estimated for the first $17.75 \mathrm{~m}$ ( 0 to $17 \mathrm{kyr} \mathrm{BP}$ ) of the
MD01-2477 core. The last $2.32 \mathrm{~m}$ (17.75 to $20.07 \mathrm{~m}$ depth) are made of a homogeneous mud displaying highly constant MS, MSA, and grain size distribution. This basal section does not show deformation or sedimentary structures. Due to its characteristics (high homogeneity and absence of a coarser sediments layer), this section could represent the upper term $(\mathrm{Hm})$ of a major $\mathrm{HmTu}$ association whose lower part was not retrieved. The measured low values of MSA may be related either to the low content of magnetic minerals in this interval (low MS values) or to an actual weak magnetic foliation. For these reasons, this $2.32 \mathrm{~m}$ thick interval is not taken in account for the statistical distribution.

In the MD01-2477 core, the magnetic susceptibility curve and the occurrence of the reworking events $(\mathrm{Tu}, \mathrm{HmTu})$ are different between the marine and non-marine succession (Figure 2). In the non-marine section the values of MS are highly variable compared to the marine section. Higher values of MS are present in the non-marine section $\left(>1000\right.$ S.I.x $\left.\times 10^{-5}\right)$. The reworking events are thinner in the non-marine section, compared to the marine one. But the HmTu deposits in both environments represent more or les the same fraction of the total sedimentation $(\sim 32.5 \%)$.

In the non-marine section the total mean sedimentation rate (hemipelagic + instantaneous deposits) is about $0.68 \mathrm{~mm} / \mathrm{yr}$, whereas the hemipelagic deposits have a sedimentation rate between 0.31 and $0.82 \mathrm{~mm} / \mathrm{yr}$. In the marine section, the total main rate of sedimentation is higher: about $1.1 \mathrm{~mm} / \mathrm{yr}$, showing rates of sedimentation in the hemipelagic deposits between 0.32 and $3.68 \mathrm{~mm} / \mathrm{yr}$.

In the non-marine section the total mean sedimentation rate (hemipelagic + instantaneous deposits) is about $0.68 \mathrm{~mm} / \mathrm{yr}$, varying from 0.31 and $0.82 \mathrm{~mm} / \mathrm{yr}$ (using hemipelagic deposits only). In the marine section, the mean sedimentation rate is about $1.1 \mathrm{~mm} / \mathrm{yr}$, varying from 0.32 and $3.68 \mathrm{~mm} / \mathrm{yr}$.

This difference in the rates of sedimentation between the marine and non-marine section can be explained by a climatic influence. The non-marine section was developed in a lowstand phase during the last glacial period (70 to $12 \mathrm{kyr} \mathrm{BP)} \mathrm{[Collier} \mathrm{et} \mathrm{al.} \mathrm{2000,}$ Lykousis et al. 2007, Bell et al. 2008] characterized, in the Mediterranean realm, by a dry and cold climate, with absence of significant tree cover (presence of steppe vegetation) [Leeder et al. 1998, Collier et al. 2000]. These climatic conditions are inferred to favour higher mechanical erosion and subsequent higher terrigenous material production. However, due to lower transport capacity of the rivers (associated to the dry conditions), these sediments were probably accumu- 


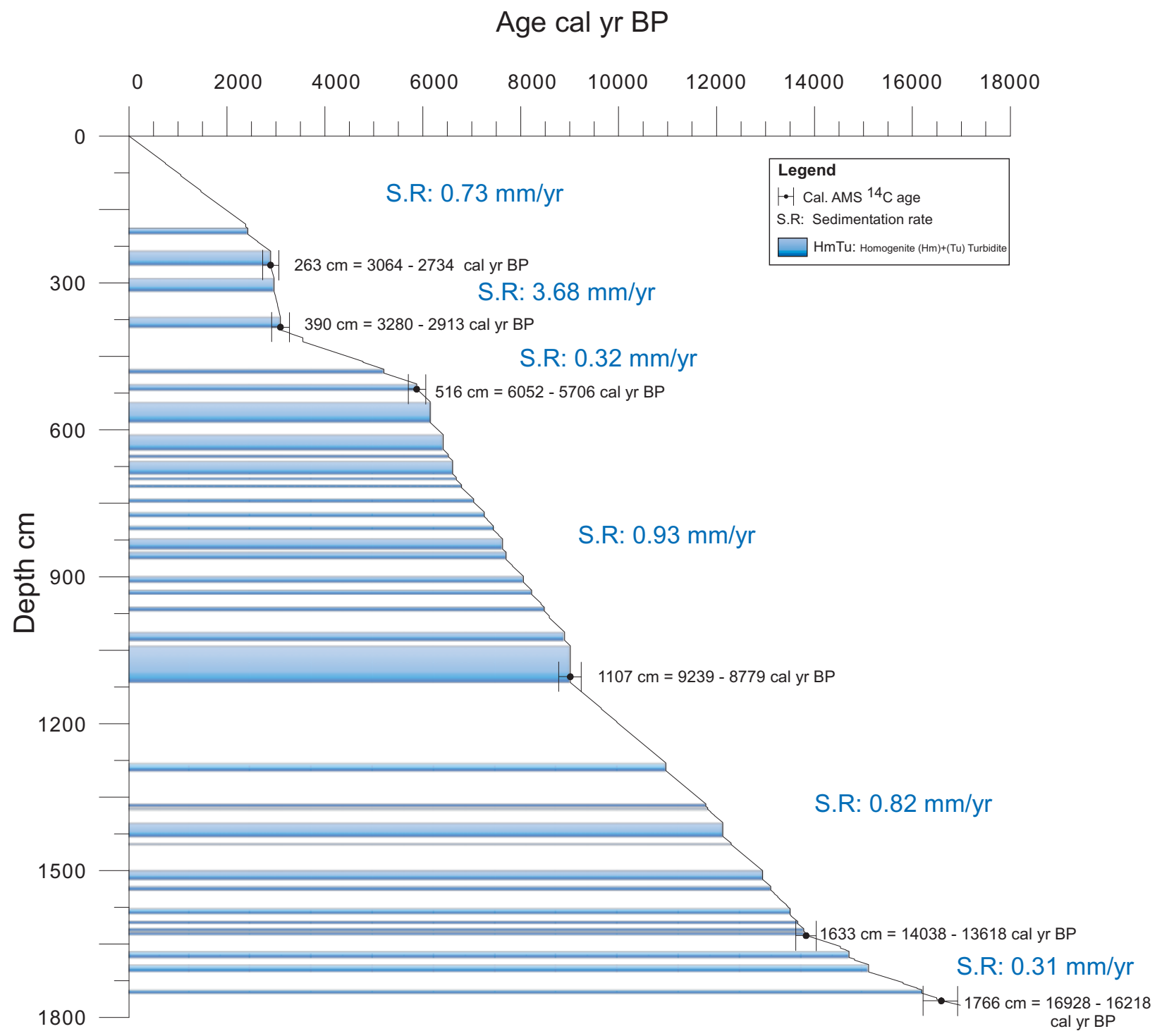

Figure 5. Proposed time distribution of HmTu events based on ${ }^{14} \mathrm{C}$ dating. Deduced sedimentation rate is applied to "hemipelagic" constant supply, without the supposed instantaneous deposits.

lated in the fluvial system or in the margin of the basin as deltas. Otherwise, during the transgressive to highstand phases associated to the Holocene glacioeustasy (12 to 0 kyr BP) [Collier et al. 2000, Lykousis et al. 2007, Bell et al. 2008], these sediments were remobilized and transported from the fluvial systems to the margin of the basin. It provides a greater amount of sediments available to be transported to the deep basin by seismic destabilization, compared to the last glacial period. Similar conditions were reported for post-glacial lakes in the French Alps and the Andes [Beck et al. 1996, Carrillo et al. 2008]. Despite this, rapid tectonic uplift, especially the southern side of the Gulf of Corinth (see Paragraph 2), has also controlled the sediment supply during the whole Quaternary. This basin combined uniform regional uplift of $0.3 \mathrm{~mm} \mathrm{yr}^{-1}$ [Collier et al. 1992] with $1.3 \mathrm{~mm} \mathrm{yr}^{-1}$ south footwall uplift [Armijo et al. 1996].
$36 \mathrm{HmTu}$ events are distributed through the MD01-2477 core, corresponding to the last $17 \mathrm{cal} \mathrm{kyr}$ BP. At the top of the core ( 0 to $2 \mathrm{~m}$ depth) and at the base of the marine section (11.2 to $12.8 \mathrm{~m} \mathrm{depth}$ ) no $\mathrm{HmTu}$ were detected, although abundant thin turbidites ( 0.5 to $1.5 \mathrm{~cm}$ thick) are present. The later ones are not thick enough to apply the here-used textural analyses, and no clear evidences for seismic origin can be assumed.

To define the recurrence time interval between two HmTu events, an age / depth curve (Figure 5) was constructed. In the 17 to $11.7 \mathrm{cal}$ kyr BP period (nonmarine section and in the marine and non-marine transition), 13 events were identified, representing a $\sim 400 \mathrm{yr}$ average recurrence interval. In the marine section (11 cal kyr BP to Present), 22 events were recognized, representing a $\sim 500 \mathrm{yr}$ average recurrence interval. According to chronological precision, the 
difference between the sections is not significant. These recurrence intervals are compatible (same order) with, or slightly larger than those proposed for the last 2 kyr period concerning the Aeghion, Skinos and Eliki Faults using palaeoseismological trenches. The later ones displayed respective recurrence intervals of $360 \mathrm{yr}$ [Pantosti et al. 2004], $330 \mathrm{yr}$ [Collier et al. 1998], and 200 to $600 \mathrm{yr}$ [McNeill et al. 2005].

Using the HmTu events may both represent:

- an over-estimation of the number of recorded earthquakes, as part of them may be only due to subaqueous lanslides. Some historical examples occurred on delta fronts on the southern coast with tsunami impact on the northern coast. In recently retrieved short cores [Mortier 2012, Beckers et al. 2013] one of these events [1963] displays a clear signature;

- an under-estimation; first, we did not include classical turbidites in our list; second, some homogenites may be not detected when a basal coarser layer is lacking. As described in the Sea of Marmara [Beck et al. 2007, Eriş et al. 2012] or in Lake Le Bourget [Chapron et al. 1999] a homogenite may just have a very thin laminae of silt/very fine sand at its base, only visible on a high resolution X-ray picture; the homogenite itself would possibly be characterized with detailed profile of MSA. These types of events have not yet been investigated here.

With respect to intensities or magnitude of involved paleo-earthquake, previous works [e.g. Audemard and De Santis 1991, Rodŕiguez-Pascua et al.2000, McCalpin 2009 and references therein, Rodríguez-Pascua et al., 2010] indicate that a $\mathrm{Mw}>5$ or 5.5 earthquake is necessary to produce noticeable geologic effects, especially pore water pressure sudden increase (driving force for liquefaction, failures, injections, etc.). Additionally, the compilation of historical data in the Gulf of Corinth [e.g. Ambraseys 1967, Papadopoulos 2003, Ambraseys and Synolakis 2010 and references therein] indicates, for the last $2.3 \mathrm{kyr}$, surface wave magnitudes comprised between $\mathrm{Ms}=7.0$ and $M s=6.0$. Most of them have generated submarine landslides and tsunamis. Based on all data, a precise estimate of paleo-magnitudes remains speculative; $\mathrm{Mw}>6$ and reaching 7 may be proposed as a realistic estimate.

\section{Conclusion}

Based on high resolution analyses of layering, composition, and, overall, textures (magnetic susceptibility, and Magnetic Susceptibility Anisotropy, grain-size distribution), the sedimentary succession sampled through the MD01-2477 core is considered as a paleoseismic archive for the last $17 \mathrm{cal} \mathrm{kyr} \mathrm{BP,} \mathrm{for} \mathrm{the} \mathrm{central}$ part of the Gulf of Corinth. Among used criteria to discuss depositional processes (instantaneous and continuous) MSA appeared to be a useful tool to identify the instantaneous homogeneous deposits $(\mathrm{Hm})$, and to distinguish them from normal hemipelagic deposits. This textural parameter also permits to precisely measure the time-equivalent of the hemipelagic interval which separates two events inferred as co-seismic ( $\mathrm{HmTu})$.

In this core, 36 earthquake-induced $\mathrm{HmTu}$ (homogenite associated to turbidite) were detected, intercalated within a continuous sedimentary recording. They can be explained by the combination of: 1) a constant seismo-tectonic activity in the Gulf of Corinth during the Late Pleistocene-Holocene. 2) terrigenous sedimentary feeding of shelves and upper slopes during the same time.

These $\mathrm{HmTu}$ events have a minimum average recurrence interval between 17 to $11.7 \mathrm{cal} \mathrm{kyr} \mathrm{BP} \mathrm{of} \sim 400$ $\mathrm{yr}$; whereas, the marine sequence, show a minimum average recurrence interval between of $\sim 500 \mathrm{yr}$. A 6.0 to 7.0 Mw approximate magnitude is considered as responsible for these sedimentary events.

In order to improve these paleoseismological studies, future investigations should include in situ geotechnical measurements to assess slope failure potential [Strasser et al. 2006, Stegmann et al. 2007]. A search of a method to discriminate earthquake-related $\mathrm{HmTu}$ and HmTu only due to landslides is also needed.

Acknowledgements. The here-presented investigations were funded through different grants and facilities: i) University of Savoie's AAP-2012-16 AGRASM Grant, dedicated to ASM sedimentological application, ii) CNRS-INSU funding through ISTerre Laboratory. iii) CNRS-INSU ARTEMIS national radiocarbon AMS measurement program. These investigations are also associated to French Agence Nationale pour la Recherche (ANR)'s SISCOR Project dedicated to seismic hazards related in the Gulf of Corinth rifting.C. Campos's $\mathrm{PhD}$ thesis and stay in ISTerre Laboratory is funded through Venezuela's FUNDAYACUCHO Grant $\mathrm{N}^{\circ}$ 20093262. We also acknowledge INQUA for the grant which permits her attend the $2^{\text {nd }}$ INQUA-ICGP 567 International Workshop on Active Tectonics, Earthquake Geology, Archaeology and Engineering. Authors are grateful to these different institutes and governments, and to two anonymous reviewers who greatly helped to improve the initial manuscript.

\section{References}

Adams, J. (1990). Paleoseismicity of the Cascadia Subduction Zone: Evidence from turbidites off the Oregon-Washington Margin, Tectonics, 9(4), 569-583.

Ambraseys, N. (1967). The earthquakes of 1965-66 in the Peloponnesus, Greece; a field report, Bulletin of the Seismological Society of America, 57, 10251046.

Ambraseys, N. and C. Synolakis (2010). Tsunami Catalogs for the Eastern Mediterranean, Revisited. Jour- 
nal of Earthquake Engineering, 14(3), 309-330.

Armijo, R., B. Meyer, G. C. P. King, A. Rigo and D. Papanastassiou (1996). Quaternary evolution of the Corinth Rift and its implications for the Late Cenozoic evolution of the Aegean, Geophysical Journal International, 126(1), 11-53.

Arnaud, F., V. Lignier, M. Revel, M. Desmet, C. Beck, M. Pourchet and F. Charlet (2002). Flood and earthquake disturbance of $210 \mathrm{~Pb}$ geochronology (Lake Anterne, NW Alps), Terra Nova, 14(4), 225-232.

Audemard, F. A. and F. De Santis (1991). Survey of liquefaction structures induced by recent moderate earthquakes, Bulletin of the International Association of Engineering Geologists, 44, 5-16.

Avallone, A., Briole, P., Agatza-Balodimou, A. M., Billiris, H., Charade, O., Mitsakaki, C., Nercessian, A., Papazissi, K., D. Paradissis and G. Veis (2004). Analysis of eleven years of deformation measured by GPS in the Corinth Rift Laboratory area. Comptes Rendus Geosci. 336, 301-311.

Beck, C. (2009). Late Quaternary lacustrine paleo-seismic archives in north-western Alps: Examples of earthquake-origin assessment of sedimentary disturbances, Earth-Science Reviews, 96(4), 327-344.

Beck, C., F. D. Manalt, E. Chapron, P. V. A. N. Rensbergen and M. D. E. Batist (1996). Enhanced Seismicity in the Early Post-Glacial Period: Evidence from the Post-Würm Sediments of lake Annecy, Northwestern Alps. Journal of Geodynamics, 22(112), 155-171.

Beck, C., B. Mercier de Lépinay, J.-L. Schneider, M. Cremer, N. Ça atay, E. Wendenbaum, S. Boutareaud, G. Ménot, S. Schmidt, O. Weber, K. Eris, R. Armijo, B. Meyer, N. Pondard, M.-A. Gutscher, and the MARMACORE Cruise Party J.-L. Turon, L. Labeyrie, E. Cortijo, Y. Gallet, H. Bouquerel, N. Gorur, A. Gervais, M.-H. Castera, L. Londeix, A. de Rességuier, A. Jaouen (2007). Late Quaternary co-seismic sedimentation in the Sea of Marmara's deep basins, in Sedimentary Records of Catastrophic Events F. Bourrouilh-Le Jan, C. Beck, D. Gorsline (Editors) Spec. Iss., Sedimentary Geology, 199, 65-89.

Beck, C., J.-L. Reyss, F. Leclerc, E. Moreno, N Feuillet and GWADASEIS Cruise Scientific Party: L. Barrier, F. Beauducel, G. Boudon, V. Clément, C. Deplus, N. Gallou, J.-F. Lebrun, A. Le Friant, A. Nercessian, M. Paterne, J.-M. Saurel, T. Pichot, C. Vidal (2012). Identification of deep subaqueous co-seismic scarps through specific coeval sedimentation, in Lesser Antilles: implication for seismic hazard D. Pantosti (Editor), Natural Hazards and Earth System Sc., Special Issue: Subaqueous Paleoseismology, 12, 1755-1767.

Beckers, A., C. Mortier, C. Beck, A. Hubert-Ferrari, J.L. Reyss, E. Tripsanas, D. Sakellariou, M. De Batist,
K. De Rycker, P. Bascou, and D. Strivay (2013). High energy environment offshore deposits in the western Gulf of Corinth, Greece, Geophysical Research Abstracts, Vol. 15, EGU2013-4877, EGU General Assembly 2013.

Bell, R. E., L. C. McNeill, M. J. Bull and T. J. Henstock (2008). Evolution of the offshore western Gulf of Corinth, Geological Society of America Bulletin, 120(1-2), 156-178.

Bernard, P., H. Lyon-Caen, P. Briole, A. Deschamps, F. Boudin, K. Makropoulos, P. Papadimitriou, F. Lemeille, G. Patau, H. Billiris, D. Paradissis, H. Castarède, O. Charade, A. Nercessian, D. Avallone, F. Pachiani, J. Zahradnik, S. Sacks and A. Linde (2006). Seismicity, deformation and hazard in the western rift of Corinth: New insights from the Corinth Rift Laboratory (CRL), Tectonophysics, 426, 7-30.

Bertrand, S., F. Charlet, E. Chapron, N. Fageland and M. De Batist (2008). Reconstruction of the Holocene seismotectonic activity of the Southern Andes from seismites recorded in Lago Icalma, Chile, $39^{\circ} \mathrm{S}$, Palaeogeography, Palaeoclimatology, Palaeoecology, 259(2-3), 301-322.

Bouma, A.H. (1962). Sedimentology of Some Flysch Deposits. Elsevier Publishing, 168 p.

Bronk Ramsey, C (2001). Development of the Radiocarbon calibration program OxCal, Radiocarbon, Proceedings of 17 th International 14C Conference, 43, 355-363.

Brooks, M. and G. Ferentinos (1984). Tectonics and sedimentation in the Gulf of Corinth and the Zakynthos and Kefallinia channels, Western Greece, Tectonophysics, 101(1-2), 25-54.

Çağatay, N., L. Erel, L. G. Bellucci, A. Polonia, L. Gasperini, K. K. Eri, Ü. Sancar, D. Biltekin, G. Uçarku, U. B. Ülgen and E. Damc1 (2012). Sedimentary earthquake records in the zmit Gulf, Sea of Marmara, Turkey, Sedimentary Geology, 282, 347-359.

Campos, C., C. Beck, C. Crouzet and E. Carrillo (2011). Characterization of Late Pleistocene-Holocene earthquake-induced "homogenites" in the Sea of Marmara through magnetic fabric. Implications for co-seismic offsets detection and measurements, Proceedings $2^{\text {nd }}$ INQUA-IGCP-567 International Workshop on Active Tectonics, Earthquake Geology, Archaeology and Engineering, Corinth, Greece, 19-21.

Campos, C., C. Beck, C. Crouzet, D. François, A. van Welden, and K. Eris. (2013) Deciphering hemipelagites from homogenites through Magnetic Susceptibility Anisotropy. Paleoseismic implications (Sea of Marmara and Gulf of Corinth), Sedimentary Geology, 292, 1-14. 
Carrillo, E., C. Beck, F. A. Audemard, E. Moreno and R. Ollarves (2008). Disentangling Late Quaternary climatic and seismo-tectonic controls on Lake Mucubají sedimentation (Mérida Andes, Venezuela), Palaeogeography, Palaeoclimatology, Palaeoecology, 259(2-3), 284-300.

Chapron, E., C. Beck, M. Pourchet and J.-F. Deconinck (1999). 1822 earthquake-triggered homogenite in Lake Le Bourget (NW Alps), Terra Nova, 11(2-3), 86-92.

Cita, M. B., A. Camerlenghi and B. Rimoldi (1996). Deep-sea tsunami deposits in the eastern Mediterranean: New evidence and depositional models, Sedimentary Geology, 104(1-4), 155-173.

Collier, R., M. R. Leeder, P. J. Rowe and T. C. Atkinson (1992). Rates of tectonic uplift in the Corinth and Megara Basins, central Greece, Tectonics, 11(6), 1159-1167.

Collier, R., D. Pantosti, G. D’Addezio, P. M. De Martini, E. Masana and D. Sakellariou (1998). Paleoseismicity of the 1981 Corinth earthquake fault: Seismic contribution to extensional strain in central Greece and implications for seismic hazard, Journal of Geophysical Research, 103(B12), 30001-30019.

Collier, R., M. R. Leeder, M. Trout, G. Ferentinos, E. Lyberis and G. Papatheodorou (2000). High sediment yields and cool, wet winters: Test of last glacial paleoclimates in the northern Mediterranean, Geology, 28(11), 999-1002.

De Batist, M., J. Klerkx, Y. Imbo, A. Giralt, V. Lignier, C. Beck and D. Delvaux. (2002). Bathymetry and sedimentary environments of Lake Issyk-Kul, Kyrgyz Republic (Central Asia): a large, high-altitude, tectonic lake, in Lake Issyk-Kul: its natural environment J. Klerkx and B. Imanackunov (Editors), NATO Science Series IV, Kluwer Academic Publ, 13, 101-124.

Dominey-Howes, D. (2002). Documentary and Geological Records of Tsunamis in the Aegean Sea Region of Greece and their Potential Value to Risk Assessment and Disaster Management, Natural Hazards, 25(3), 195-224.

Eri , K., N. Çağatay by K. Eriş, N. Çağatay, B. Mercier de Lepinay and C. Campos (2012). Late-Pleistocene to Holocene sedimentary fills of the Çinarcık Basin of the Sea of Marmara, Sedimentary Geology, 281, 151-165.

Folk R. L. and W. C. Ward (1957). Brazos River bar: a study in the significance of grain size parameters, Journal of Sedimentary Petrology, 27, 3-26.

Galanopoulos, A. G., P. Comninakis and N. Delibasis (1964). A tsunami generated by an earth slump set in motion without shock, Annales Géologiques des Pays. Helléniques, 16, 93-110.

Goldfinger, C., C. H. Nelson and J. E. Johnson (2003). Holocene Earthquake records from the Cascadia subduction zone and northern San Andreas Fault based on precise dating of offshore turbidites, Annual Review of Earth and Planetary Sciences, 31(1), 555-577.

Goldfinger, C. (2009). Subaqueous Paleoseismology, in Paleoseismology J. McCalpin (Editor), 2nd edition, Elsevier, 119-169.

Gorsline, D. S., T. D. Diego and E. H. Nava-Sanchez (2000). Seismically triggered turbidites in small margin basins: Alfonso Basin, Western Gulf of California and Santa Monica Basin, California Borderland, Science, 135, 21-35.

Hasiotis, T., G. Papatheodorou, G. Bouckovalas, C. Corbau and G. Ferentinos (2002). Earthquake-induced coastal sediment instabilities in the western Gulf of Corinth, Greece, Marine Geology, 186(3-4), 319-335.

Hempton, M. R. and J. F. Dewey (1983). Earthquake-induced deformational structures in young lacustrine sediments, East Anatolian Fault, southeast Turkey, Tectonophysics, 98(3-4), 7-14.

Hrouda, F. E. K. (1982). Magnetic anisotropy of rocks and its application, Surveys in Geophysics, 5, 37-82.

Huh, C.-A. (2004). Linkages between turbidites in the southern Okinawa Trough and submarine earthquakes, Geophysical Research Letters, 31(12), 2-5.

Jackson, J. A., J. Gagnepain, G. Houseman, G. C. P. King, P. Papadimitriou, C. Soufleris and J. Virieux (1982). Seismicity, normal faulting and the geomorphological development of the Gulf of Corinth (Greece): the Corinth earthquakes of February and March 1981, Earth and Planetary Science Letters, 57(2), 377-397.

Jelinek, V. (1981). Characterization of the magnetic fabric of rocks, Tectonophysics, 79(3-4), 63-67.

Jolivet, L. (2001). A comparison of geodetic and finite strain pattern in the Aegean, geodynamic implications, Earth and Planetary Science Letters, Volume 187(1-2), 95-104.

Joseph, L. H., D. K. Rea and B. A.Van der Pluijm (1998). Use of Grain Size and Magnetic Fabric Analyses to Distinguish Among Depositional Environments, Paleoceanography, 13(5), 491-501.

Kastens, K. and M. B. Cita (1981). Tsunami-induced sediment transport in the abyssal Mediterranean Sea, Geological Society of America Bulletin, 92(11), 845-857.

Le Pichon, X., J. Angelier, M. F. Osmaston and L. Stegena (1981). The Aegean Sea [and Discussion], Philosoph- 
ical Transactions of the Royal Society of London, Series A, Math. Phys. Sc., 300(1454), 357-372.

Le Pichon, X., N. Chamot-Rooke, S. Lallemant, R. Noomen and G. Vets (1995). Geodetic determination of the kinematics of central Greece with respect to Europe: Implications for eastern Mediterranean tectonics, Journal of Geophysical Research, 100(B7), 12675-12690.

Leeder, M. R., T. Harris and M. J. Kirkby (1998). Sediment supply and climate change: implications for basin stratigraphy, Basin Research, 10(1), 7-18.

Levi, T., R. Weinberger, T. Aïfa, Y. Eyal and S. Marco (2006). Earthquake-induced clastic dikes detected by anisotropy of magnetic susceptibility, Geology, 34(2), 69-72.

Lignier, V. (2001). Les sédiments lacustres et l'enregistrement de la palæoséismicité. Etude comparative de différents cas dans le Quaternaire des Alpes Nord-Occidentales et du Tien-Shan Kyrghize, Unpublished Doct, Thèse, Université de Savoie, 2 vol., $330 \mathrm{pp}$.

Lowe, D. R. (1982). Sediment gravity flows; II, Depositional models with special reference to the deposits of high-density turbidity currents, Journal of Sedimentary Research, 52(1), 279-297.

Lykousis, V., D. Sakellariou, I. Moretti and H. Kaberi (2007). Late Quaternary basin evolution of the Gulf of Corinth: Sequence stratigraphy, sedimentation, fault-slip and subsidence rates, Tectonophysics, 440(1-4), 29-51.

Lykousis, V., G. Roussakis and D. Sakellariou (2009). Slope failures and stability analysis of shallow water prodeltas in the active margins of Western Greece, northeastern Mediterranean Sea, International Journal of Earth Sciences, 98(4), 807-822.

Marco, S. and A. Agnon (1995). Prehistoric earthquake deformations near Masada, Dead-Sea graben, Geology, 23(8), 695-698.

McCalpin, J. (2009). Paleoseismology, 2nd edition, Elsevier, 119-169.

McClusky, S., S. Balassanian, A. Barka, C. Demir, S. Ergintav, I. Georgiev and O. Gurkan (2000). Global Positioning System constraints on plate kinematics and dynamics in the eastern Mediterranean and Caucasus, Journal of Geophysical Research, 105(B3), 5695-5719.

McHugh, C. M., L. Seeber, N. Braudy, M.-H. Cormier, M. B. Davis, J. B. Diebold and N. Dieudonne (2011). Offshore sedimentary effects of the 12 January 2010 Haiti earthquake, Geology, 39(8), 723-726.

McKenzie, D. (1972). Active Tectonics of the Mediterranean Region, Geophysical Journal of the Royal Astronomical Society, 30(2), 109-185.
McKenzie, D. (1978). Active tectonics of the Alpine-Himalayan belt: the Aegean Sea and surrounding regions, Geophys. J. Royal Astr. Soc., 55(1), 217-254.

McNeill, L. C., R. Collier, P. M. De Martini, D. Pantosti and G. D'Addezio (2005). Recent history of the Eastern Eliki Fault, Gulf of Corinth: geomorphology, palaeoseismology and impact on palaeoenvironments, Geophysical Journal International, 161(1), 154-166.

Moretti, I., D. Sakellariou, V. Lykousis and L. Micarelli (2003). The Gulf of Corinth: an active half graben?, Journal of Geodynamics, 36(1-2), 323-340.

Moretti, I., V. Lykousis, D. Sakellariou, J.-Y. Reynaud, B. Benziane and A. Prinzhoffer (2004). Sedimentation and subsidence rate in the Gulf of Corinth: what we learn from the Marion Dufresne's long-piston coring, Comptes-Rendus Geosciences, 336(4-5), 291-299.

Mörner, N-A. (1996). Liquefaction and varve deformation as evidence of paleoseismic events and tsunamis. The autumn 10,430 BP case in Sweden, Quaternary Science Review, 15(8), 939-948.

Mörner, N-A. and G. Sun (2008). Paleoearthquake deformations recorded by magnetic variables, Earth and Planetary Science Letters, 267(3-4), 495-502.

Mortier, C. (2012). Etude sédimentologique dans la partie occidentale du Golfe de Corinthe (Grèce). MSc. Memoir, University of Liège, $129 \mathrm{p}$.

Mulder, T. and J. Alexander (2001). The physical character of subaqueous sedimentary density flows and their deposits, Sedimentology, 48(2), 269-299.

Mutti E. and F. Ricci Lucchi (1978). Turbidites of the northern Apennines: introduction to facies analysis, American Geological Institute, Reprint Series 3, 127-166.

Mutti, E., R. Tinterri, E. Remacha, N. Mavilla, S. Angella and L. Fava (1999). An introduction to the analysis of ancient turbidite basins from an outcrop perspective: American Association of Petroleum Geology, Continuing Education Course Note Series, 39, 95.

Nakajima, T. and Y. Kanai (2000). Sedimentary features of seismoturbidites triggered by the 1983 and older historical earthquakes in the eastern margin of the Japan Sea, Sedimentary Geology, 135(1-4), 1-19.

Pantosti, D., P. M. De Martini, I. Koukouvelas, L. Stamatopoulos, N. Palyvos, S. Pucci and F. Lemeille (2004). Palaeoseismological investigations of the Aigion Fault (Gulf of Corinth, Greece), Comptes-Rendus Geosciences, 336(4-5), 335-342.

Papadopoulos, G. A. (2003). Tsunami Hazard in the Eastern Mediterranean: Strong Earthquakes and Tsunamis in the Corinth Gulf, Central Greece, Natural Hazards, 29(3), 437-464. 
Papatheodorou, G. and G. Ferentinos (1997). Submarine and coastal sediment failure triggered by the 1995, M, = 6.1 R Aegion earthquake, Gulf of Corinth, Greece, Holocene, Marine Geology, 137(3), 287-304.

Passega, R. (1964). Grain Size Representation by CM Patterns as a Geological Tool, SEPM, Journal of Sedimentary Research, Vol. 34(4), 830-847.

Perissoratis, C., D. Mitropoulos and I. Angelopoulos (1984). The role of earthquakes in inducing sediment mass movements in the eastern Corinthiakos Gulf: an example from the February 24-March 4 activity, Marine Geology, 55, 35-45.

Perissoratis, C., D. J. Piper and V. Lykousis (2000). Alternating marine and lacustrine sedimentation during late Quaternary in the Gulf of Corinth rift basin, central Greece, Marine Geology, 167(3-4), 391-411.

Piper, D. J. W. and W. R. Normark (2009). Processes That Initiate Turbidity Currents and Their Influence on Turbidites: A Marine Geology Perspective, Journal of Sedimentary Research, 79(6), 347-362.

Reimer, P. J and F. G. McCormac (2002). Marine radiocarbon reservoir corrections for the Mediterranean and Aegean Seas, Radiocarbon, 44, 159-166.

Reimer, P. J., M. G. L. Baillie, E. Bard, A. Bayliss, J. W. Beck, P. G. Blackwell, C. Bronk Ramsey, C. E. Buck, G. S. Burr, R. L. Edwards, M. Friedrich, P. M. Grootes, T. P. Guilderson, I. Hajdas, T. J. Heaton, A. G. Hogg, K. A. Hughen, K. F. Kaiser, B. Kromer, F. G. McCormac, S. W. Manning, R. W. Reimer, D. A. Richards, J. R. S. Southon Talamo, C. S. M. Turney, J. van der Plicht and C. E. Weyhenmeyer (2009). IntCal09 and Marine09 radiocarbon age calibration curves, 050,000 years cal BP, Radiocarbon, 51(4), 1111-1150.

Rodríguez-Pascua, M. A., V. H. Garduño-Monroy, I. Israde-Alcántara and R. Pérez-López (2010). Estimation of the paleoepicentral area from the spatial gradient of deformation in lacustrine seismites (Tierras Blancas Basin, Mexico), Quaternary International, 219(1-2), 66-78.

Rodríguez-Pascua, M. A., J. P. Calvo, G. De Vicente and D. Gómez-Gras (2000). Soft-sediment deformation structures interpreted as seismites in lacustrine sediments of the Prebetic Zone, SE Spain and their potential use as indicators of earthquake magnitudes during the Late Miocene, Sedimentary Geology, 135(1-4), 117-135.

Sakellariou, D., V. Lykousis and D. Papanikolaou (2001). Active faulting in the Gulf of Corinth, Greece, F. Briand (Editor), 36th CIESM Congress, 43.

Shiki, T., M. B. Cita and D. S. Gorsline (2000). Sedimentary features of seismites, seismo-turbidites and tsunamiites - an introduction, Sedimentary Geol- ogy, 135, 7-9.

Siegenthaler, C., W. Finguer, K. Kelts and W. Suming (1987). Earthquake and seiche deposits in Lake Lucerne, Switzerland, Ecloae Geologiae Helvetae, 80(1), 241-260.

Stefatos, A., G. Papatheodorou, G. Ferentinos, M. Leeder, and R. Collier (2002). Seismic reflection imaging of active offshore faults in the Gulf of Corinth: their seismotectonic significance, Basin Research, 14(4), 487-502.

Stegmann, S., M. Strasser, F.S. Anselmetti and A. Kopf (2007). Geotechnical in situ

characterisation of subaquatic slopes: The role of pore pressure transients versus frictional strength in landslide initiation, Geophysical Research Letters, 34, L07607.

Strasser, M., F.S Anselmetti, D. Fäh, D. Giardini and M. Schnellmann (2006). Magnitudes and source areas of large prehistoric northern Alpine earthquakes revealed by slope failures in lakes, Geology, 34 (12), 1005-1008.

Sturm, M., C. Siegenthaler and R.A. Pickrill (1995). Turbidites and "homogenites": a conceptual model of flood and slide deposits, Publication of the International Association of Sedimentologists, 16th Regional Meeting, Paris, 22:40.

Syvitski, J. P. M and C. T. Schafer (1996). Evidence for an earthquake-triggered basin collapse in Saguenay Fjord, Canada, Sedimentary Geology, 104(1-4), 127-153.

Tarling, D. H and F. E. K. Hrouda (1993). The Magnetic Anisotropy of Rocks, Chapman \& Hall, London, $218 \mathrm{p}$.

Thunell, R., E. Tappa, R. Varela, M. Llano, Y. Astor, F. Muller-Karger and R. Bohrer (1999). Increased marine sediment suspension and fluxes following an earthquake, Nature, 398, 233-236.

Van Loon, A. J., K. Brodzikowski and T. Zielinski (1995). Shock-induced resuspension deposits from a Pleistocene proglacial lake (Kleszczow Graben, central Poland), Journal of Sedimentary Research, 65(2), 417-422.

\footnotetext{
${ }^{\star}$ Corresponding author: Corina Campos,

Universidad Simón Bolívar, Departamento de Ciencias de la Tierra, Sartenejas, Baruta, Venezuela; email: campossc@usb.ve

C 2013 by the Istituto Nazionale di Geofisica e Vulcanologia. All rights reserved.
} 